\title{
Floral traits as potential indicators of pollination vs. theft
}

\author{
Camila Silveira de Souza ${ }^{1,3}$, Camila Aoki ${ }^{2}$, Augusto Ribas ${ }^{1}$, Arnildo Pott ${ }^{1}$ \& Maria Rosângela Sigrist ${ }^{1}$
}

\begin{abstract}
Floral visitation does not necessarily mean pollination, as several animals utilize floral resources without transferring pollen. Since pollinators and thieves can affect the reproduction, morphology and diversification of flowering plants, we here investigated if attributes of flowers and flowering of plant species collected in the central Brazilian vereda would predict the pollination (pollen seeking) or theft (pollen/nectar theft) during the visits. It was hypothesized that non specialized flowers would have a higher incidence of thievery, where as specialization, for example, the presence of large and medium flowers with long corolla, making it difficult to access nectar, would lead to increased pollination. As a result, four attributes were mainly associated with illegitimate visits, and in order of importance, they are size (small), quantity of flowers per plant (large), flowering time ( $<10$ months) and floral type (inconspicuous). The richest and most abundant visitor groups, including bees, flies and wasps, acted mainly as potential pollinators, while cockroaches, butterflies, beetles, ants and hemipterans acted as thieves. However, further studies are required to confirm that this pattern is repeated in other larger and more diverse communities, thus confirming the possible preference for floral thieves.

Key words: vereda, bees, anthophilous fauna, flowering, generalist flower.

\section{Resumo}

Tipos florais de plantas como potenciais indicadores da ocorrência de polinização vs. pilhagem. A visitação floral não é sinônimo de polinização, vários animais utilizam recursos florais sem transferir pólen. Essas visitas podem ser consideradas pilhagem. Polinizadores e pilhadores podem afetar a diversificação morfológica, taxonômica e reprodutiva das espécies de plantas, e nós investigamos se os atributos florais e de floração das espécies de plantas amostradas em vegetação de vereda nos dariam evidência de visitas de polinização (transporte de pólen) ou de pilhagem (roubo de néctar/pólen). Esperamos que as flores não especializadas tenham uma maior incidência de pilhagem, enquanto flores especializadas, por exemplo com tamanho grande e médio e corolas longas, com néctar menos acessível, tenderiam a ser polinizadas e menos pilhadas. Quatro atributos foram associados principalmente com visitas ilegítimas, tamanho da flor (pequeno), quantidade de flores por planta (muitas flores), tempo de floração (<10 meses) e tipo floral (inconspícuo). Os grupos mais ricos e mais abundantes de visitantes, incluindo abelhas, moscas e vespas, atuaram principalmente como potenciais polinizadores, enquanto baratas, borboletas, besouros, formigas e hemípteros atuaram como pilhadores. No entanto, mais estudos são necessários para confirmar se esse padrão se repete em outras comunidades maiores e mais diversificadas, confirmando assim a eventual preferência dos pilhadores.
\end{abstract}

Palavras-chave: vereda, abelhas, fauna antófila, floração, flor generalista.

\section{Introduction}

Mutualistic relationships occur in all ecosystems and contribute to the generation and maintenance of diversity in different habitats or communities (Rech \& Brito 2012). These interactions can be categorized as trophic, defensive or dispersive, as well as obligate or facultative (Ricklefs 2001; Thompson 2005). Interactions between flowers and the animals that visit them are an example of dispersive

\footnotetext{
${ }^{1}$ Universidade Federal de Mato Grosso do Sul, Centro de Ciências Biológicas e da Saúde, Lab. Polinização, Reprodução e Fenologia de Plantas, Cidade Universitária s/n, , 79070-900, Campo Grande, MS, Brazil.

${ }^{2}$ Universidade Federal de Mato Grosso do Sul, Campus Universitário de Aquidauana, R. Oscar Trindade de Barros 740, Bairro Serraria, 79200-000, Aquidauana, MS, Brazil.

${ }^{3}$ Author for correspondence: souza.camila.bio@gmail.com
} 
mutualism. In this case, animals obtain floral resources, e.g., nectar, resins, or oils, and, in return, transport and disperse pollen between flowers and plants, thus performing pollination (Rech \& Brito 2012).

Pollination units, such as flower blossoms or inflorescences (sensu Faegri \& van der Pijl 1979), are visited by a large variety of floral visitors (Faegri \& van der Pijl 1979; Corlett 2004). Importantly, however, flower visitation does not necessarily mean pollination (Waser et al. 1996; Waser et al. 2015). Thus, in some cases, only floral visitors reap benefits since they are not all effective pollinators (Inouye 1980; Strauss \& Whittall 2006; Irwin et al. 2010). In this sense, floral visitors can either act as pollinators or thieves, indicating that these mutualistic and antagonistic interactions are part of a continuum and that visitor species can have multiple behaviors within their respective repertories (Rech \& Brito 2012). Within such continuum, flower morphology is fundamental because floral traits can restrict access to floral resources and thus prevent visits from the antagonists visits (Olesen et al. 2007; Vázquez et al. 2009).

Therefore, within a community, plant species compete for pollination services (Waser 1983), but also present barriers against would be thieves (Gonzálvez et al. 2013). In this sense, the floral or flowering traits of a given species derive from a set of distinct selective pressures when pollinators and thieves may share the same preferences. Althought we have clues on selection pressure exerted by thieves (Strauss \& Whittall 2006), few studies have explored the relative selection pressure of this group or its floral preferences (e.g., Maruyama et al. 2015). Furthermore, while robbers may negatively influence plant reproduction by reducing floral attractiveness to pollinators, they may also have a positive influence by either increasing the number of flowers the pollinators must visit or by increasing travel distances to obtain their daily energy requirements (Irwin et al. 2010; Maruyama et al. 2015).

Since pollinators and thieves can affect the morphology and diversification of plants (Strauss \& Whittall 2006), as well as reproduction, we herein investigated whether attributes of flowers and flowering of plant species collected in the central Brazilian vereda would be useful to predict pollinating or antagonistic visits. To accomplish this, we conducted a survey of floral visitors and verified their pollination performance on the sampled species. We considered some floral attributes as less specialized, e.g., small nectariferous flowers, with resources accessible to all visitors, assembled in collective or congested pollination units, and produced in large quantity. We hypothesized that such attributes would tend to be less restrictive and thus allow the indiscriminate visitation of several groups of visitors, or generalists, to the floral resources, thereby increasing the chance of antagonistic visits.

\section{Material and Methods}

\section{Study area}

This study was carried out from September 2012 to August 2013 in a vereda wetland of the Área de Proteção Ambiental (APA) Guariroba (20³2'39''S, 54'23'54''W), which supplies water to the urban area of Campo Grande, Mato Grosso do Sul, Brazil, and is located $35 \mathrm{~km}$ to the north (Dias 2005) (Fig. 1a). The study area consists of approximately 1.44 ha and is surrounded by pasture, cerrado stricto sensu, cerrado woodland and eucalyptus. Typical of vereda vegetation, the palm Mauritia flexuosa is the most abundant tree in the area (Fig. 1b).

The study area consists of three distinct stages: an outer part with an open grassland, an intermediate shrubland, and an innermost part with tree species. In the innermost part, the water table is lower, and running water is found, as well as humid soil (Fig. 1b).

The climate of the region is tropical Aw (Köppen 1948), with a warm and rainy season from October to March, a warm and dry period from April to September, and a transitional season in July. Annual rainfall is approximately 1400 $\mathrm{mm}$, with mean temperatures ranging from 21 and $26^{\circ} \mathrm{C}$ (Vilas Boas et al. 2013).

\section{Sampling}

Fieldwork was conducted monthly in eight fixed plots of $50 \mathrm{~m} \times 3 \mathrm{~m}$ (10 m apart), crossing the vereda in a westerly direction (Fig. 1c). Sampling of the diurnal floral visitors was conducted on all flowered plants between $07 \mathrm{~h} 30$ and $17 \mathrm{~h} 30$. Each flowering plant found in the transect was sampled for ten minutes; however, sampling time depended on species occurrence and abundance, resulting in an observation time for each individual ranging from 10 to 9900 minutes (565.66 \pm 846.26$)$ (Tab. 1). 


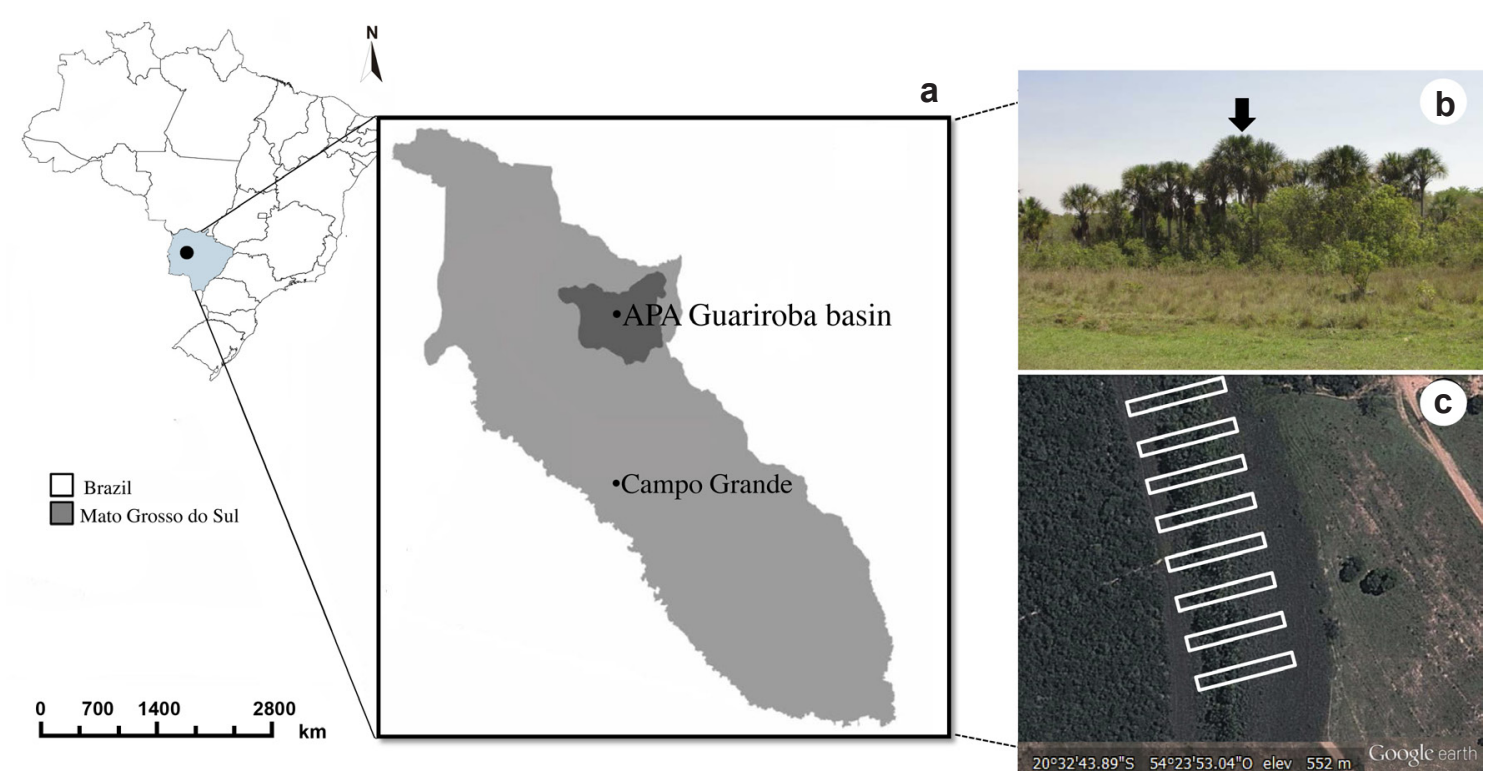

Figure 1 - a. Map of the Área de Proteção Ambiental (APA) Guariroba, Campo Grande, Mato Grosso do Sul, Brazil. b. front view of vegetation of the studied vereda wetland, showing the "buriti" palm Mauritia flexuosa (arrow), a typical vegetation type of this area, in the background. c. aerial view showing the approximate distribution of plots in the study area (source: Google Earth).

We excluded Poaceae spp., which are generally anemophilous (sensu Faegri \& van der Pij1 1979; Proctor et al. 1996). Most sampled species have herbaceous habit $(47 \%)$, followed by sub-shrubs $(19 \%)$, shrubs $(16 \%)$, trees $(12 \%)$ and climbers $(7 \%)$ (sensu Guedes-Bruni et al. 2002). Vouchers of the sampled plant species were collected, dried, identified and deposited in the Herbarium CGMS of the Universidade Federal de Mato Grosso do Sul, Campo Grande (Tab. 1). Botanical identification was achieved after consulting a specialized bibliography, the herbarium CGMS, and specialists. Plant names followed APGIII (2009) and Mobot (2011).

For all species, the following attributes were verified: number of flowering months, number of flowers per individual, organization (solitary flowers or assembled in inflorescences) and dimension (large: $>10 \mathrm{~mm}$; medium: $>5 \mathrm{~mm}$ and $<10 \mathrm{~mm}$; small: $<5 \mathrm{~mm}$ ) of the pollination units (visited flower or inflorescence), main color (yellow, blue, white, brown, pink, purple, green), symmetry (actinomorphic, zygomorphic). Following this analysis, the flowers were classified into floral types as described in Machado \& Lopes (2004) (Tab. 1).
During the study period, we recorded only insects in pollination units. These insects were collected with entomological nets and kept in glass jars with ethyl acetate or alcohol $70 \%$. Later, they were pinned or stored in alcohol, morphotyped and sent to specialists for identification. Classification of insect groups followed Corlett (2004). Performance of the floral visitor as a pollinator was determined through observations of intrafloral behavior, analysis of photographic records, floral morphology and/or the size relationship between flower and visitor. The visitor was considered a potential pollinator when it touched anthers to receive pollen and stigma to deposit it. The visitor was considered a thief of pollen or nectar (sensu Inouye 1980; adapted as described in Irwin et al. 2010) if it did not show such behavior while collecting floral resource. Specimens of floral visitors were deposited in the Zoological Collection of the Universidade Federal de Mato Grosso do Sul (ZUFMS), Museu de Zoologia of Universidade de São Paulo (MZUSP), Museu de História Natural/ Zoologia of Universidade Federal da Bahia (MHNBA/MZUFBA) and private collections of some taxonomists (e.g., Ayr de Moura Bello). 


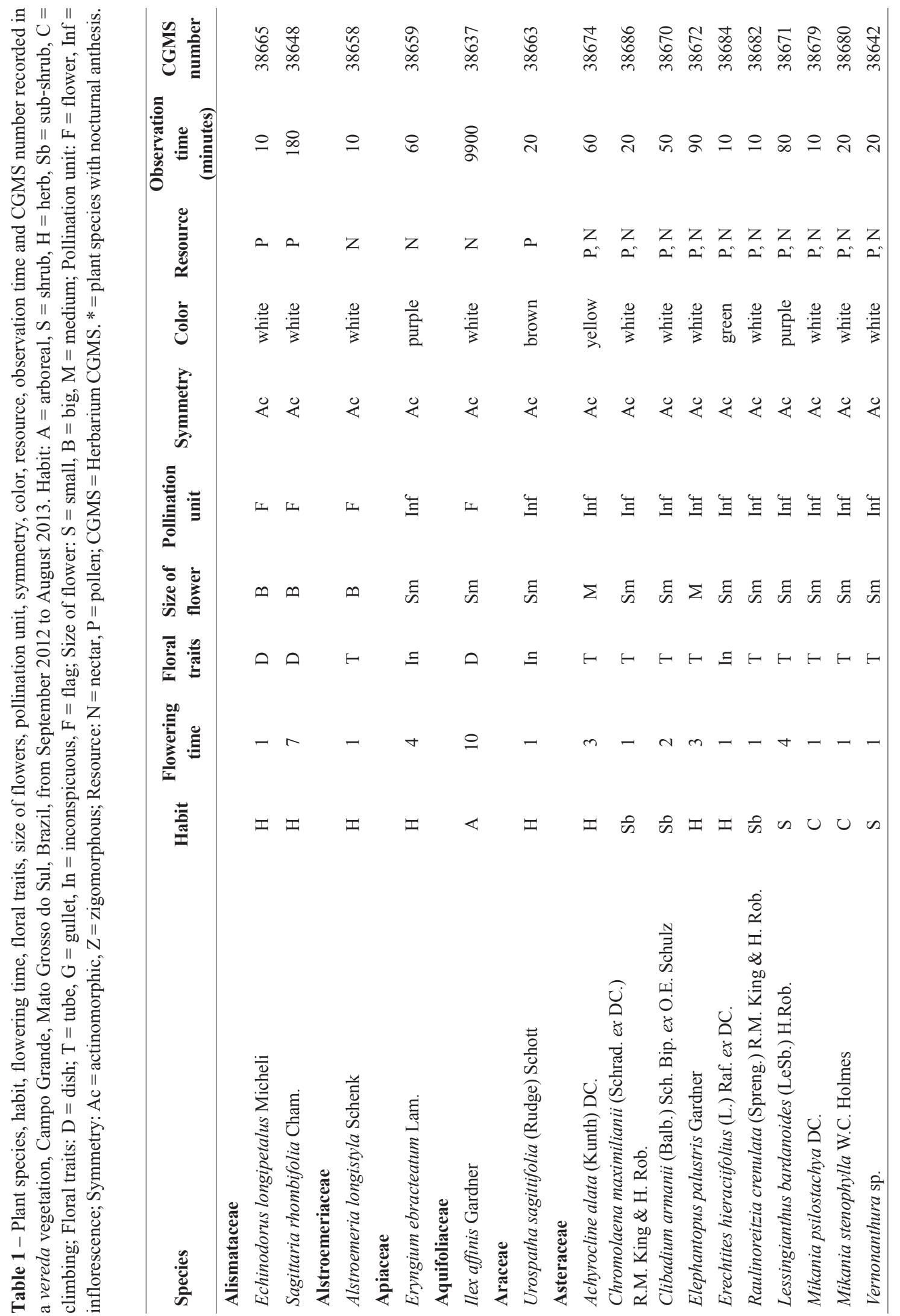




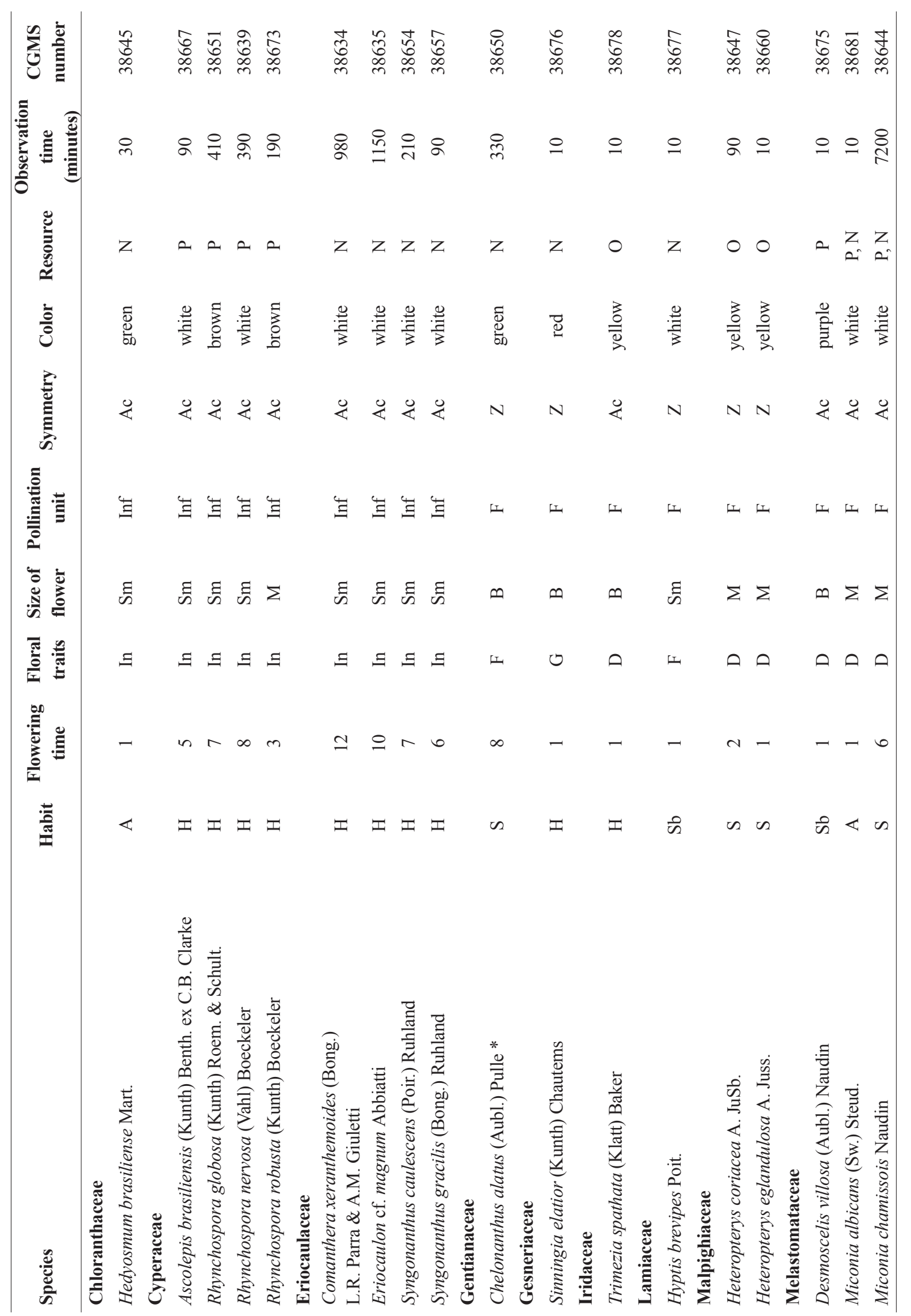




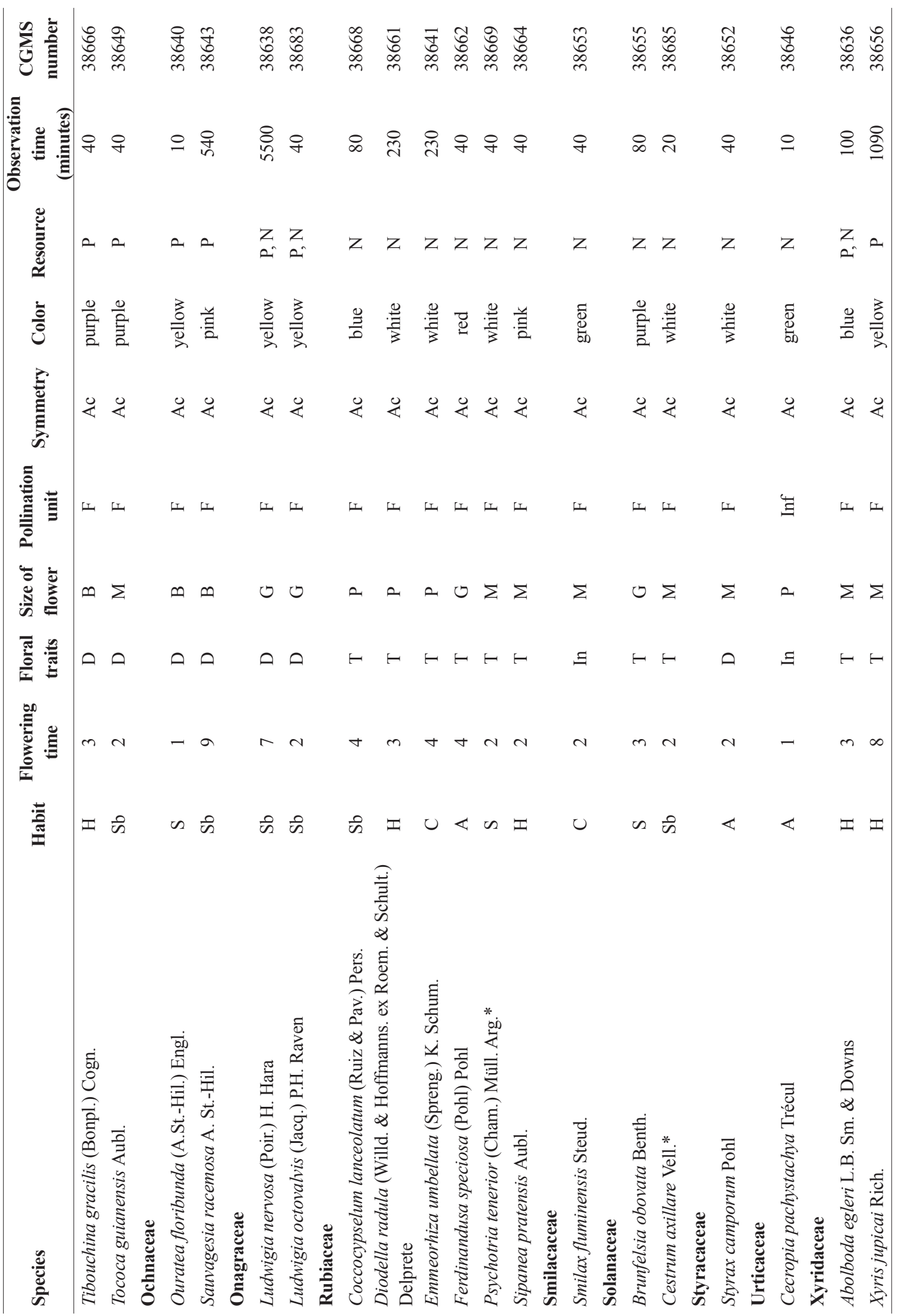


Table 2 - Floral attributes, classification of variable type and characteristics used in the construction of the decision tree with the plant species of the vereda in Campo Grande, Mato Grosso do Sul, Brazil, from September 2012 to August 2013.

\begin{tabular}{|c|c|c|c|}
\hline Attributes & Variable type & Characteristics and number of samples observed & $\begin{array}{l}\text { Total of each } \\
\text { partition to the } \\
\text { decision tree }\end{array}$ \\
\hline $\begin{array}{l}\text { (1) Number of flowers } \\
\text { per plant }\end{array}$ & Numerical & Minimum 1; Maximum 1900; Median 32; Average 156 & 38,43 \\
\hline (2) Flower color & Categorical & $\begin{array}{l}\text { Yellow - 99; Blue - 1; White - 263; Brown - 21; Pink - 3; } \\
\text { Purple - 4; Green - } 10\end{array}$ & 10,71 \\
\hline (3) Floral symmetry & Categorical & Actinomorphic - 397; Zygomorphic - 4 & 0 \\
\hline (4) Floral type & Categorical & $\begin{array}{l}\text { Inconspicuous - 98; Dish - 258; Tube - 42; Gullet - 1; } \\
\text { Flag - } 3\end{array}$ & 15,81 \\
\hline (5) Anthesis & Categorical & Diurnal - 396; Nocturnal - 5 & 0 \\
\hline (6) Resource pollen & Categorical & Absent - 204; Present - 197 & 8,14 \\
\hline (7) Resource nectar & Categorical & Absent - 95; Present - 306 & 1,86 \\
\hline $\begin{array}{l}\text { (8) Flowering time } \\
\text { (number of months) }\end{array}$ & Numerical & Minimum 1; Maximum 11; Median 8 & 20,96 \\
\hline (9) Flower size & Categorical & Big - 120; Medium - 66; Small - 215 & 6,54 \\
\hline (10) Inflorescence type & Categorical & Collective $=24 ;$ No collective $=29$ & 2,96 \\
\hline
\end{tabular}

\section{Data Analysis}

Classification trees are suited for the analysis of complex ecological data, which, in our case, involved a set of continuous and categorical predictors. This method can also treat nonlinear relationships and high-order interactions, which inflate the number of parameters needed for regression models commonly used (De'Ath Fabricius 2000). Therefore, we utilized this method of recursive partitioning to generate a classification decision tree, as suggested by Breiman et al. (1984). This method aims to ordinate, in a more parsimonious way, the behaviors of pollination and theft based on 10 attributes and 401 samples. The utilized attributes were (1) number of flowers per plant, (2) flower color, (3) floral symmetry, (4) floral type, (5) anthesis, (6) pollen as resource, (7) nectar as resource, (8) flowering time, (9) size of flower and (10) type of inflorescence (Tab. 2).

We also ran a $10 \mathrm{k}$-fold cross-validation to evaluate the fitness of the model compared with other possible models and determine if the model improved our predictability of the behaviors of pollination and theft. We computed the accuracy and cross-tabulated the observed and predicted classes, calculating their probabilities for the model we present here. To calculate the importance of each attribute for the decision tree, the reduction in the mean square error contributed by each attribute to each partition was calculated, and the sum is presented in Table 2. The attributes which were candidates for partition, but not utilized, were also considered for each partition, as proposed by Quinlan (1992). All analyses were performed utilizing $\mathrm{R}$ language ( $\mathrm{R}$ Core Team 2015) with the rpart package (Therneau et al. 2015) to generate the classification tree and caret packages (Kuhn 2015) for cross-validation and importance attribute calculations.

\section{Results}

In the 53 sampled plant species, flowering time varied from one to eleven months, with most plants typically flowering between one and four months $(73.1 \%)$. The number of pollination 
Table 3 - Group, richness, abundance and behavior of floral visitors sampled in plant species of vereda vegetation, in Campo Grande, Mato Grosso do Sul, Brazil, from September 2012 to August 2013. The last two columns are the percentage of the species in the group that perform with thieves or pollinators of the plant species visited.

\begin{tabular}{lccccc}
\hline Group & $\begin{array}{c}\text { Richness } \\
(\mathbf{n})\end{array}$ & $\begin{array}{c}\text { Abundance } \\
(\mathbf{n})\end{array}$ & $\begin{array}{c}\text { Number of plant } \\
\text { species visited (n) }\end{array}$ & $\begin{array}{c}\text { Pollination } \\
(\mathbf{\%})\end{array}$ & $\begin{array}{c}\text { Thief } \\
\mathbf{( \% )}\end{array}$ \\
\hline Bees & 37 & 131 & 19 & 100 & 0 \\
Spiders $^{\mathrm{a}}$ & 3 & 3 & 3 & - & - \\
Cockroaches $_{\text {Beetles }}$ & 1 & 1 & 1 & 0 & 100 \\
Butterflies & 6 & 17 & 7 & 58,8 & 41,2 \\
Ants & 4 & 20 & 9 & 35 & 65 \\
Crickets & 6 & 60 & 13 & 0 & 100 \\
Hemipterans & 6 & 8 & 4 & - & - \\
Flies & 5 & 13 & 3 & 0 & 100 \\
Wasps & 46 & 77 & 12 & 93,5 & 6,5 \\
\hline
\end{tabular}

${ }^{\mathrm{a}}$ predation; ${ }^{\mathrm{b}}$ feeding on floral parts

units per plant varied from 1 to 1900 , most plants having 1-10 flowers $(60 \%)$ or $200-500(38 \%)$ (Tab. 1). Solitary flowers predominated $(54 \%)$ over those assembled in inflorescences (45\%). With respect to size, small flowers $(43.3 \%)$ were the most representative, followed by large (32\%) and medium flowers (24.5\%). Most species displayed white $(45.3 \%)$, yellow $(15.1 \%)$ or lilac/ violet/purple pollination units $(13.2 \%)$; the others were brown, pink, red, blue or green $(26.4 \%)$. Five floral types were recorded: tube $(37.7 \%)$, dish (30.1\%), flag (3.77\%), inconspicuous $(26.4 \%)$ and gullet $(1.88 \%)$. Flowers with nectar $(65 \%)$ were more frequent than those with only pollen $(29.3 \%)$ or oil $(5.7 \%)$. Actinomorphic flowers (96.2\%) with diurnal anthesis $(90 \%)$ predominated. Visits to individual flowers $(54.7 \%)$ were slightly higher than visits to inflorescence (45.2\%) (Tab. 1).

The pollination units of thirty plant species were visited by 138 species of insects, herein categorized into ten groups in decreasing order of richness: flies, bees, wasps, crickets, beetles, ants, hemipterans, butterflies, spiders and cockroaches. Bees, flies and wasps were the most abundant groups and visited the largest number of plant species, together with ants (Tab. 3). Most studied groups behaves as thieves, including a high percentage of butterflies, all species of ants, hemipterans and cockroaches. In this study, all floral thieves were observed collecting nectar or pollen and exhibited one morphological mismatch between flower and the thieves body, thus preventing pollination from taking place. Spiders probably predated other floral visitors, and crickets ate floral parts, including stamens (Tab. 3); therefore they are not proper flower visitors and so they were not included in the analyzes (Tab. 3). Bees, flies and wasps acted as potential pollinators.

Based on our hypothesis, which holds that decreasing specialization correlates with theft, while increasing specialization correlates with pollination, species with small, inconspicuous flowers, plants with a high number of flowers $(>500)$ and flowering time shorter than 10 months would have a greater chance of illegitimate visits to the pollination units. In contrast, large or medium-sized flowers with tube or dish floral type, long flowering period ( $>10$ months) and plants with a variable number of flowers (but $<$ 500 ) would stand a greater chance of becoming pollinated (Tab. 2; Fig. 2). The classification tree had an accuracy of $82 \%$, and the cross-validation results are as follows: $10 \%$ for true theft, $72.1 \%$ true pollination, $4.2 \%$ false theft and $13.7 \%$ for false pollination. 


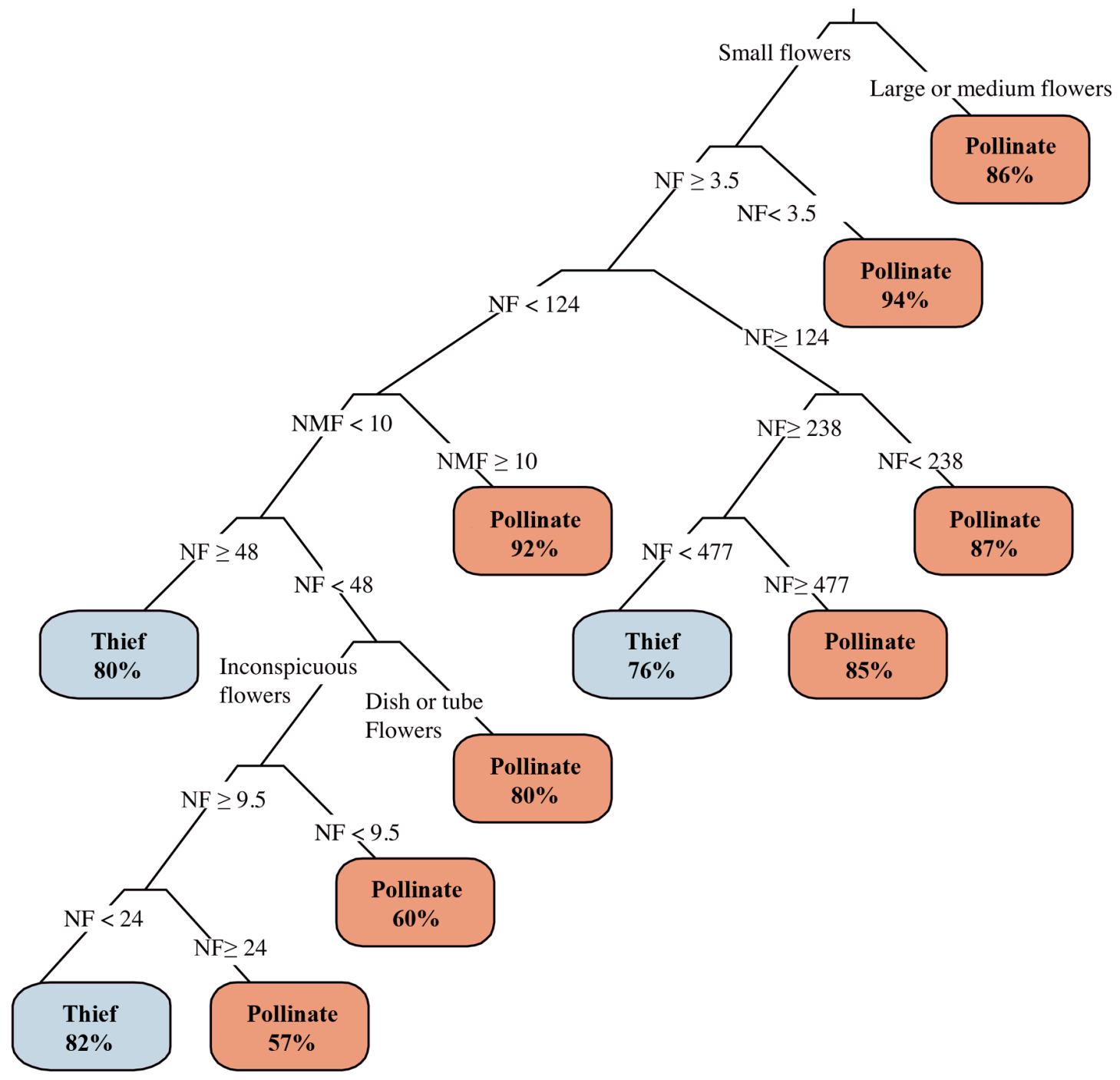

Figure 2 - Decision tree with the floral attributes and the probability of pollination or theft in a vereda community, Campo Grande, Mato Grosso do Sul, Brazil. Percentage indicates the probability of occurrence of theft or pollination. $\mathrm{NF}=$ number of flowers; $\mathrm{NMF}=$ number of months in flowering.

\section{Discussion}

\section{Composition}

Data obtained from floral and flowering characteristics in the studied vereda community are in accordance with results observed in other savanna communities (Freitas \& Sazima 2006) and other physiognomies of the cerrado biome, i.e, predominance of diurnal, nectariferous, actinomorphic and light-colored flowers (e.g., Silberbauer-Gottsberger \& Gottsberger 1988; Barbosa 1997; Oliveira \& Gibbs 2000).
Considering anthophilous fauna, the groups of insects recorded in the community were similar to those found in other vegetation types of cerrado (Aoki \& Sigrist 2006), grasslands (Freitas \& Sazima 2006; Pinheiro et al. 2008) or anthropic habitats, such as eucalyptus plantations (Lopes et al. 2007). In our study, the richest and most abundant groups, including bees, flies and wasps, were mainly potential pollinators of the sampled plant species. Bees are known as the main and most efficient pollinators in tropical vegetation 
types (Oliveira \& Gibbs 2000; Freitas \& Sazima 2006; Silva et al. 2012). Nectar and pollen constitute the main source of carbohydrates and proteins for bees, respectively, for nourishment of brood and adults (Faegri \& van der Pijl 1979; Barbola et al. 2000). Flies are one of the most important groups of floral visitors (Kevan \& Baker 1999; Larson et al. 2001), as adults can consume large amounts of pollen and nectar (Larson et al. 2001; Morales \& Köhler 2008), and some groups of diptera are highly specialized flower visitors and important pollinators of several plant species (e.g., Endara et al. 2010; Kearnes 2001). Furthermore, appropriate behavior and morphological adjustment on these groups in the flower visitation, causes them to be important pollinators of plant species.

In contrast, it was surprising that a high percentage of theft was recorded for butterflies, particularly because this group depends on floral nectar and has historically been considered as pollinators (Faegri \& van der Pijl 1979; Proctor et al. 1996). The other studied insects, are commonly sampled on flowers and are generally not considered as "habitual" pollinators, except beetles (Proctor et al. 1996). Hence ants were the main thieves recorded in our study, tending to visit flowers with exposed nectar (Herrera et al. 1984; Ballantyne \& Willmer 2012).

\section{Floral traits and thieves}

In this study, nonspecialized flowers were those having a higher frequency of thieves. The traits more related to thieving were: plants with small and inconspicuous flowers, high number of flowers, and flowering time under 10 months. These results confirm our hypothesis that nonspecialized flowers have a higher incidence of thievery, whereas specialization, for example, the presence of large and medium flowers with long corolla, making it difficult to access nectar, leads to increased pollination (Stang et al. 2006). Thus, theft correlates with the incompatible morphology between plant and animal visitor that gains access to the resource without offering pollen transfer (Irwin et al. 2001). In small and inconspicuous pollination units, including flowers and inflorescences, the floral resource is generally more accessible to the visiting fauna, in particular those with short mouthparts, such as ants, beetles, cockroaches and hemipterans, all groups with a high percentage of theft in this study.

The number of flowers per plant and flowering time were more important features than flower shape as indicators of frequent illegitimate visits. For example, while a larger number of flowers could help to increase floral display, acting to attract a wider range of visitors, legitimate or illegitimate, such displays could also indirectly represent higher amounts of available resources, a situation which seems to increase the chances of theft in this vereda community. In contrast, a smaller quantity of flowers may be more efficient in reducing geitonogamous pollination and promote cross pollination, in addition to reducing stigma obstruction with unsuitable pollen in self-incompatible species (Wyatt 1982).

Flowering time can promote the temporal variation of the resources, and in this study, most species flowered for up to four months $(>70 \%)$, although some flowered for up to 11 months, which is favorable for maintenance of floral visitors. In an assessment of impact of floral theft at different levels, Irwin et al. (2001) reported that theft could be related to flowering season of the plant species. Irwin \& Maloof (2002) suggest that the direction and magnitude of theft could depend on the relative temporal and spatial abundance of thieves and pollinators and their synchrony with the flowering period of the visited species.

Thus, the net effects of cheating for plant reproduction can be negative, positive, or neutral. Thieves (morphological uncoupling) may have more subtle indirect effects on plant fitness, for example by altering the interaction between plants and pollinators. The result may be to decrease plant fitness if larceny reduces floral rewards sufficiently for pollinators to avoid a plant or to desert it after a brief visit (Inouye 1983; Wootton 1993; Maloof and Inouye 2000; Irwin et al. 2001).

According to Irwin et al. (2001), the evolution of floral traits surely must be understood, in part, with reference to pollinators. However for the plant, the selection environment includes larcenists, and other plant enemies, as well as mutualists. The net direction and magnitude of selection will likely depend on the relative abundances in space and time of robbers and pollinators.

In conclusion, other researches including color measurement, functional characteristics of nectar, quantitative measurement of odor and the corolla tubes are encouraged to better understand the floral traits that can predict the cheating in pollination. Also, efficiency measures for each visitor should be performed in the future. Furthermore, the pollinators in vereda community and other formations are part of a bigger network of interactions where plants, pollinators and larcenists are embedded. Plants with robbed flowers grow sympatrically with other plant species that share larcenists and/or pollinators 
(Irwin et al. 2001). Thus, future studies investigating the role of these thieves in community interactions network should be encouraged in order to better understand the pressures and effects of thieves in the vereda community.

\section{Acknowledgements}

Programa de Pós-graduação em Biologia Vegetal for logistical support, CAPES, for financial support, anonymous reviewers for their valuable suggestions. Eric Okiyama Hattori, Geraldo Alves Damasceno-Junior, Nara Mota Furtado, Suzana Neves Moreira and Vali Joana Pott, for identification of plant species. Favízia Freitas de Oliveira (bees), Ramon Mello, Daniel Maximo C. de Alcantara, Carlos José Einicker Lamas and Mirian Nunes Morales (flies), Rodrigo Aranda (wasps), Ayr de Moura Bello (beetles, hemiptera), Andressa Figueiredo (hemiptera), Renan da Silva Olivier (crickets), Danilo Ribeiro (butterflies), Paulo Robson de Souza (ants), for identification of floral visitors. Flávia Maria Leme, Tamires Soares Yule, João Roberto Fabri, Tiago G. de Freitas, Thiago Henrique Stefanello, Aline Parreira da Costa, Damião Teixeira de Azevedo, Danielle Boin Borges, Evaldo Benedito de Souza, Fabio Kochanovscki Junior, Franciélle Oliveira, Jacqueline A. Rotta, Jéssica Placência, Milton Omar Cordova Neyra, Muryel Furtado de Barros, Rafaela Thaller and Vivian Almeida Assunção, for help with fieldwork. Hannah Doerrier, for English revision.

\section{References}

Aoki, C. \& Sigrist, M.R. 2006. Inventário dos visitantes florais no Complexo Aporé-Sucuriú. In: Pagoto, T.C.S. \& Souza, P.R. (ed.). Biodiversidade do Complexo Aporé-Sucuriú. Subsídios à conservação e ao manejo do Cerrado. Editora da Universidade Federal de Mato Grosso do Sul, Campo Grande. Pp. 143-162.

APG III. 2009. An update of the Angiosperm Phylogeny Group classification for the orders and families of flowering plants: APG III. Biological Journal of the Linnean Society 161: 105-121.

Ballantyne, G. \& Willmer, P. 2012. Nectar theft and floral ant-repellence: a Link between nectar volume and ant-repellent traits? Plos one 7: 1-10.

Barbola, I.F.; Laroca, S. \& Almeida, M.C. 2000. Utilização de recursos florais por abelhas silvestres (Hymenoptera, Apoidea) da Floresta Estadual do Passa Dois (Lapa, Paraná, Brasil). Revista Brasileira de Entomologia 44: 9-19.

Barbosa, A.A.A. 1997. Biologia reprodutiva de uma comunidade de campo sujo em Uberlândia, MG.
Tese de Doutorado em Ecologia. Universidade Estadual de Campinas, Campinas. 202p.

Breiman L.; Friedman, J.H.; Stone, C.J \& Olshen, R.A. 1984. Classification and regression trees (Wadsworth Statistics/Probability). Chapman and Hall/CRC, Belmont. 368p.

Corlett, R.T. 2004. Flower visitors and pollination in the Oriental (Indomalayan) Region. Biological Reviews 79: 497-532.

De'ath G. \& Fabricius K.E. 2000. Classification and regression trees: a powerful yet simple technique for ecological data analysis. Ecology 81: 3178-3192.

Dias, E.F. 2005. Georreferenciamento no estudo do uso e ocupação do solo na microbacia do Guariroba no município de Campo Grande, MS. Monografia, Universidade Católica Dom Bosco, Campo Grande. 81p.

Endara, L.; Grimaldi, D.A. \& Roy, B.A. 2010. Lord of the flies: pollination of Dracula orchids. Lankesteriana 10: 1-11.

Faegri K. \& van der Pijl, L. 1979. The principles of pollination ecology. $3^{\text {rd }}$ ed. Pergamon Press, Oxford. 244p.

Freitas, L. \& Sazima, M. 2006. Pollination biology in a tropical high-altitude grassland in Brazil: interactions at the community level. Annals of the Missouri Botanical Garden 93: 465-520.

Gonzálvez, F.G.; Luis Santamaría, L.; Richard T. Corlett, R.T. \& Rodríguez-Gironés, M.A. 2013. Flowers attract weaver ants that deter less effective pollinators. Journal of Ecology 101: 78-85.

Guedes-Bruni, R.R.; Morin, M.P.M.; Lima, H.C. \& Sylvestre, L.S. 2002. Inventário florístico. In: Sylvestre, L.S. \& Rosa, M.M.T. (org.). Manual metodológico para estudos botânicos na Mata Atlântica. Editora Seropédica, Rio de Janeiro. Pp. 24-49.

Herrera, C.M.; Herrera, J \& Espadaler, X. 1984. Nectar thievery by ants from southern Spanish insectpollinated flowers. Insectes Sociaux 31: 142-154.

Inouye, D.W. 1980. The terminology of floral larceny. Ecological Society of America 61: 1251-1253.

Irwin, R.E.; Brody, A.K. \& Waser, N.M. 2001. The impact of floral larceny on individuals, populations, and communities. Oecologia 129: 161-168.

Irwin, R.E.; Bronstein, J.L.; Manson, J.S. \& Richardson, L. 2010. Nectar robbing: ecological and evolutionary perspectives. Annual Review of Ecology, Evolution, and Systematics 41: 271-292.

Kearns, C.A. 2001. North american dipteran pollinators: assessing their value and conservation status. Conservation Ecology 5. Available at <http:// www.consecol.org/vol5/iss1/art5/>. Access on 22 April 2015.

Kevan, P.G. \& Baker, H.G. 1999. Insects and flowers. In: Huffaker, C.B. \& Guttierrez, A.P. (eds.). Ecological 
Entomology. Vol. 2. Wiley and Sons, New York. Pp. 553-584.

Köppen, W. 1948. Climatologia: con un estudio de los climas de la tierra. Fondo de Cultura Econômico, Cidade do México. 479p.

Kuhn, M. 2015. Contributions from Wing, J.; Weston, S.; Williams, A.; Keefer, C.; Engelhardt, A.; Cooper, T.; Mayer, Z. \& Kenkel, B. The R Core Team, Benesty, M.; Lescarbeau, R.; Ziem, A. \& Scrucca, L. Caret: classification and regression training. $\mathrm{R}$ package version 6.0-47. Available at $<$ http://CRAN.R-project. org/package $=$ caret $>$. Access on 25 April 2015.

Larson, B.M.H.; Kevan, P.G. \& Inouye, D.W. 2001. Flies and flowers: taxonomic diversity of anthophiles and pollinators. The Canadian Entomologist 133: 439-465.

Lopes, L.A.; Blochtein, B. \& Ott, A.P. 2007. Diversidade de insetos antófilos em áreas de reflorestamento de eucalipto, Município de Triunfo, Rio Grande do Sul, Brasil. Iheringia 97: 181-193.

Machado, I.C. \& Lopes, A.V. 2004. Floral traits and pollination systems in the Caatinga, a Brazilian Tropical Dry Forest. Annals of Botany 94: 365-376.

Maruyama, P.K.; Vizentin-Bugoni, J.; Dalsgaard, B.; Sazima, I. \& Sazima, M. 2015. Nectar robbery by a hermit hummingbird: association to floral phenotype and its influence on flowers and network structure. Oecologia 178: 783-793.

Mobot - Missouri Botanical Garden. 2011. Tropicos. (org.). Available at $<$ http://www.tropicos.org $>$. Access on 3 June 2014.

Morales, M.N. \& Köhler, A. 2008. Comunidade de Syrphidae (Diptera): diversidade e preferências florais no Cinturão Verde (Santa Cruz do Sul, RS, Brasil). Revista Brasileira de Entomologia 52: 41-49.

Olesen, J.M.; Dupont, Y.L.; Ehlers, B.K. \& Hansen, D.M. 2007. The openness of a flower and its number of flower-visitor species. Taxon 56: 729-736.

Oliveira, P.E. \& Gibbs, P. 2000. Reproductive biology of wood plants in cerrado community of Central Brazil. Flora 195: 311-329.

Pinheiro, M.A.; Harter-Marques, B.E. \& Miotto, S.T.S. 2008. Floral resources used by insects in a grassland community in Southern Brazil. Revista Brasileira de Botânica 31: 469-489.

Proctor, M.; Yeo, P. \& Lack, A. 1996. The natural history of pollination. Timber Press, Portland. 487p.

Quinlan, J. 1992. Learning with continuous classes. Proceedings of the 5th Australian Joint Conference On Artificial Intelligence. World Scientific, Singapore. Pp. 343-348.

R Development Core Team. 2012. R: a language and environment for statistical computing. R Foundation for Statistical Computing. Available at $<$ https:// www.r-project.org/>. Access on 22 April 2015.

Rech, A.R. \& Brito, V.L.G. 2012. Mutualismos extremos de polinização: história natural e tendências evolutivas. Oecologia Australis 16: 297-310.

Ricklefs, R.E. 2001. A economia da natureza. Vol. 5. Guanabara Koogan, Rio de Janeiro. 542p.

Silberbauer-Gottsberger, I. \& Gottsberger, G. 1988. A polinização de plantas do Cerrado. Revista Brasileira de Biologia 48: 651-663.

Silva, C.I.; Araújo, G. \& Oliveira, P.E.A.M. 2012. Distribuição vertical dos sistemas de polinização bióticos em áreas de cerrado sentido restrito no Triângulo Mineiro, MG, Brasil. Acta Botanica Brasilica 26: 748-760.

Stang, M.; Klinkhamer P.G.L. \& van der Meijden, E. 2006. Size constraints and flower abundance determine the number of interactions in a plantflower visitor web. Oikos 112: 111-121.

Strauss, S.Y. \& Whittall, B. 2006. Non-pollinator agents of selection on floral traits. In: Harder, L.D. \& Barret, S.C.H. (eds.). Ecology and evolution of flowers, Oxford. Pp. 120-138.

Therneau, T.; Atkinson, B. \& Ripley, B. 2015. rpart: recursive partitioning and regression trees. $\mathrm{R}$ package version 4.1-9. Available at $<$ http:// CRAN.R-project.org/package $=$ rpart $>$. Access on 25 April 2015.

Thompson, J.N. 2005. The geographic mosaic of coevolution. The Universtity of Chicago Press, Chicago \& Londres. 400p.

Vázquez, D.P.; Blüthgen, N.; Cagnolo, L. \& Chacoff, N.P. 2009. Uniting pattern and process in plantanimal mutualistic networks: a review. Annals of Botany 103: 1445-1457.

Vilas Boas, J.C.; Fava, W.S.; Laroca, S. \& Sigrist, M.R. 2013. Two sympatric Byrsonima species (Malpighiaceae) differ in phenological and reproductive patterns. Flora 208: 360-369.

Waser, N.M. 1983. The adaptive nature of floral traits: ideas and evidence. In: Real, L. (ed.). Pollination biology. Academic Press, London. Pp. 241-285.

Waser, N.M.; Chitkka, L.; Price, M.V.; Williams, N.M. \& Ollerton, J. 1996. Generalization in pollination systems, and why it matters. Ecology 77: 1043-1060.

Waser, N.M.; Ollerton, J. \& Price, M.V. 2015. Response to Aguilar et al.'s (2015) critique of Ollerton et al. 2009. Journal of pollination ecology 17: 148-149.

Wyatt, R. 1982. Inflorescence Architecture: how flower number, arrangement, and phenology affect pollination and fruit-set. American Journal of Botany 69: 585-594. 